Volume 11, Issue 12, December 2020, pp. 108-117. Article ID: IJM $11 \_12013$

Available online at http://iaeme.com/Home/issue/IJM?Volume $=11 \&$ Issue $=12$

Journal Impact Factor (2020): 10.1471 (Calculated by GISI) www.jifactor.com

ISSN Print: 0976-6502 and ISSN Online: 0976-6510

DOI: 10.34218/IJM.11.12.2020.013

\title{
AN EMPIRICAL ANALYSIS OF INTER- INDUSTRY AND INTRA-INDUSTRY TRADE BETWEEN INDIA AND ASEAN - THE IMPACT OF REVEALED COMPARATIVE ADVANTAGE (RCA) IN COMMODITIES
}

\author{
Chumki Handique \\ Research Scholar, Department of Economics, \\ Dibrugarh University, Assam, India
}

\begin{abstract}
International co-operation or integration among countries is quite common in today's world. India and the ASEAN (Association of South-East Asian Nations) countries have an illustrious history of mutual cooperation for more than 25 years with a shared goal of economic prosperity through strategic convergence. The deepening of ties in mutually beneficial trade between India and ASEAN nations is reflected in the continued buoyancy in trade figures recently (\$142 billion in 201819). This paper tries to shed some light on the most recent trends and patterns in the trade scenario between India and ASEAN-5 nations (inter-industry as well as intraindustry). Here, the five original members of ASEAN are considered (i.e. Indonesia, Malaysia, Philippines, Singapore, and Thailand which also are the largest economies among ASEAN members. The status of trade among these countries is important because there has been increase in total trade among these countries recently. Many reports and surveys have confirmed a potential increase in economic integration in future which will contribute to economic growth in these regions. Furthermore, the Revealed Comparative advantage (RCA) index is constructed for the commodities in which simultaneous imports and exports has been taking place during the study period that is 2000-2017. The RCA index gives the result whether a country has a comparative advantage in the production of a certain commodity or not. The study seeks to answer the research question whether the level of intra-industry trade increase when a country has revealed comparative advantage in case of the production of certain commodities?
\end{abstract}


Key words: RCA index, intra-industry, inter-industry, trade, import, export.

Cite this Article: Chumki Handique, An Empirical Analysis of Inter-Industry and Intra-Industry Trade between India and ASEAN - The Impact of Revealed Comparative Advantage (RCA) in Commodities, International Journal of Management, 11(12), 2020, pp 108-117.

http://iaeme.com/Home/issue/IJM?Volume $=11 \&$ Issue $=12$

\section{INTRODUCTION}

India-ASEAN mutual association auspicated in 1992 when India became a sectoral dialogue partner of ASEAN (Association of South-East Asian Nations). Following that, ASEAN had offered India to become its full dialogue partner in 1995 (in the fifth ASEAN Summit), and the member of the ASEAN Regional Forum (ARF) in 1996. Since 2002, India and ASEAN often takes part in summit level -meetings every year. From its start, the integration between India and ASEAN has been growing at a rapid pace. The major objective behind the same was not only to promote development of the society, cultural development, regional peace and stability, mutual assistance and to explore all avenues for better exploitation of geographical proximity and natural endowments among themselves, but also to devise a means of escape from dependence on the more prosperous global markets (Kahler, 1995).Verdoorn (1960) and Balassa (1966), for the first time noticed a unique pattern of trade among the OECD countries. They noticed simultaneous import and export of the same goods within a same industry. This original H-O theory however, is incapable of explaining this unique pattern of trade which came to be known as intra-industry trade.

The terms inter-industry' and intra-industry' trade, although are very similar in sound, have very different inherent meanings conceptually. Inter-industry refers to the trade among different industries in different products. For example, when trade takes place between two countries and one country exports agricultural products and imports technological equipment produced in another country, it is classified as inter-industry trade. On the other hand, when one country imports agricultural products and also exports agricultural products, such trade is called intra-industry trade.

As it has been noted in many studies, "intra-industry trade (IIT), that is trade of similar products, has been a key factor in trade growth in recent decades. These trends have mostly been attributed to the fragmentation of production (outsourcing and offshoring) as a result of globalisation and new technologies" (Handjiski et al, 2010).

Two examples of intra-industry and inter-industry trade scenarios are- Suppose, country A is a capital abundant country and country B is a labour abundant country. In the first instance, country A exports manufacturing goods which is produced using more capital and less labour (in which they have comparative advantage) and imports food product. And country B exports food which it produces using its abundant labour, and import manufacturing goods. This pattern of trade is called inter-industry trade. In the second scenerios, country A imports as well as exports food products. This type of trade is known as intra-industry trade.

The importance of intra-industry trade for the trading countries can be explained with the help of the following points-

Comparative advantage is not always necessary- Intra industry trade occurs when a country has comparative advantage in the production of a commodity. Products are usually differentiated in terms of quality, (Roy, 1999). Many empirical studies established the fact that intra-industry trade have taken place even when a country possess no comparative advantage, in contrast to the preceding theories which argued that trade takes place due to 
comparative advantage. So, even when a country has no comparative advantage, it can still engage in intra-industry trade.

Equitable income distribution prevails- According to Stopler-Samuelson theorem, international trade causes redistribution of resources among the trading partners i.e. income from a country having scarce factors are reallocated to a country having abundant factors due to increased demand for abundant factors. This causes unequal income distributions. But, this impact in less likely to occur when trade is intra-industry in nature as in such trade is not based on the abundant or scarce factors availability as it doesn't require comparative advantage.

Stimulates innovation in the industries - Intra- industry trade is all about product differentiation and consumers responsiveness to variety of products. In response to what consumers want, greater competition prevails. Competition leads to innovation and better technology in production. When a variety of goods and commodities are produced in a country, in the process the knowledge, skill and technologies involved in the production keeps on increasing. It helps in reducing the cost of production and promotes innovations.

Advantages from scale economies- Intra-industry trade leads to better exploitation of economies of scale. It means, Average costs of production declines when the scale of output increases. Working in a very specific and particular product leads to specialisation in that product. As a result production takes place at a large scale and manufacturing or adjustment costs declines because of the savings of fixed costs of setting up a new factory or unit. The focus is more on quality of products rather than number of products. All these leads to expansion of output and increases the gains from trade through economies of scale.

All these benefits indicates that intra-industry trade represents world trade in a better way by creating a larger market better gains from trade. It is more likely that the advantages and benefits from intra-industry trade would accrue to each trading partner rather than being concentrated in the developed and abundant ones.

\section{REVIEW OF EMPIRICAL LITERATURE}

The original Heckscher-Ohlin theory, (developed by Eli Heckscher and Bertil Ohlin in 1919), is one of the most influential as well as controversial theories in international economics. The Heckscher-Ohlin theory is also known as the 'Factor-proportions theory'. It is because the Heckscher-Ohlin theory focuses mainly on the proportions in which different factors of production are available in different countries. It assumes that international trade is largely driven by differences in countries' resources. The basic proposition of the model is that a country that is abundant in a factor of production will export the good which is intensively produced with the abundant factor. This original $\mathrm{H}-\mathrm{O}$ theory however, is incapable of explaining the phenomena of intra-industry trade. Some writers have still tried to explain the intra-industry trade. A prominent attempt was made in this regard by R.E. Falvey in 1981. He recognised product differentiation as an important but widely neglected variable while considering the case of intra-industry trade.. Thus, Falvey's model came to be known as the 'Neo-Heckscher- Ohlin model'. Krugman (1979), in his paper titled, 'Increasing Returns, Monopolistic Competition, And International Trade,' developed a simple model of trade in which trade which differs from most other formal treatments. His study summarised that trade is not caused by differences in relative factor endowments or technology rather trade may simply be a way to extend the market and allow for exploitation of economies of scale. A. J. Venable's model, is an extension of Krugman's model in which there is production of identical product under the conditions of constant costs. It assumes a situation in which one country specialises in the production of homogeneous good, while the other country specialises in the production of differentiated goods and discusses the possible existence of 
multiple equilibria in such situations. The model that rests upon the approach suggested by K.J. Lancaster (1980) are known a Neo- Hotelling models. In his paper, Lancaster applied the analysis of perfect monopolistic competition to the problem of intra-industry trade. He showed that a high volume of intra-industry trade can take place even between economies in which there is the existence of comparative advantage. Ajit Kumar Jha and Sanjoy Saha (2011), studied the trade patterns of ASEAN-5 since the implementation of AFTA (ASEAN Free Trade Area) in 1992. They estimated the overall ASEAN-5 intra-industry trade as well as country specific intra-industry trade by constructing the Grubel-Lloyed index to study the trend in intra-industry trade. The index is constructed as the weighted average of the intraindustry trade of the individual commodities. Jay Dev Dubey (2016). Ram Upendra Das, Meenakshi Rishi and some others, in their paper analyses the relation that exists between Revealed Comparative advantage and intra-industry trade between ASEAN-6 countries and India. They investigate this relationship not only in terms of linear relationship, but also examined whether the rate of change in RCA leads to changes in Intra-industry trade. They concluded that the actual relationship between IIT and RCA is left-skewed or is characterized by a positive skew. This implies that India's IIT with the ASEAN+5 region increases at a much faster rate for the initial values of RCA, when RCA values are quite low.

\section{OBJECTIVES}

The study tries to address the following two objectives and a research question-

- To study the trend and pattern of intra-industry and inter-industry trade between India and ASEAN-5 countries.

- To measure the Revealed Comparative advantage of India and ASEAN-5 nations and to analyse its relationship with intra-industry trade.

\section{Research Question}

Does the level of intra-industry trade increase when a country has revealed comparative advantage in producing of a commodity?

\section{MATERIALS AND METHODS}

Secondary data on imports and exports of India and ASEAN have been taken from WITS (World Integrated Trade Solution) database managed by World Bank Group, ASEAN Statistical Yearbooks, The ASEAN Secretariat and various reports and publications etc. Data regarding economic conditions like GDP etc. are taken from World Bank database. The classification of product groups in which intra-industry trade has taken place is based on ITCHS code (Indian Trade Classification based on Harmonized System of Coding) in the currently revised list of 2018.

ITC-HS code, better known as Indian Trade Classification based on Harmonized System of Coding was adopted in India for better import-export operations. In India. An eight digit ITC (HS) code is used for the trade analysis in India. All the products in the list are categorised into 21 groups and the 21 groups are sub-divided into 98 chapters i.e. from HS code- 01 to HS code- 98 . The products in each chapter are further divided starting from a 4 digit sub-headings group up to an 8 digit sub-heading group. For example- chapter HS-06 belongs to vegetable products. 06 here signifies the product group vegetables under which different sub-groups such as trees, plants, bulbs, roots, flowers etc. are present. These sub groups are categorised as starting from 4-digit code like $0601,0602,0603$ etc., further into 6 digit code such as $06022,06023,06024$ etc. finally up to 8 digit code such as 06022112 , 06022113,06022114 etc. These 8 digit is the unique code for each commodity under the category chapter-06 which signifies a particular type of product-vegetables. Here, 8 digit is 
the lowest level of aggregation while 2 digit is the highest level of aggregation. Normally, it is assumed that a 6 digit level or an 8 digit level implies an industry. In this study, 8 digit level is considered as an industry which contains the summation of all the values of products at 4 and 6 digit level.

After analysing the whole HS code for simultaneous imports and exports between India and ASEAN-5, the following 14 items have been found to have an appropriate Intra industry trade between India and ASEAN-5 Nations.

The currency used to represent trade between India and ASEAN is US \$ (in millions). The commodities used for constructing RCA index are-vegetables, Food products, minerals, chemical industries, plastics, raw hides, skins, rubbers and furs, wood products, textiles, footwear/headgear, stone/ glass, metals, machinery/electrical, transportation and miscellaneous.

The revealed comparative advantage (RCA) index has been constructed for the year 20002017 for the commodities in which simultaneous exports and imports takes place between India and ASEAN-5 nations. For country $i$ in product $j$, the index is calculated as follows-

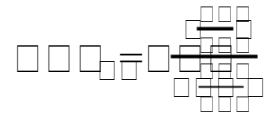

Where,

Xij and Xwi are country i's exports of product $\mathrm{j}$ and world exports of product $\mathrm{j}$.

Xit and Xwt stands for country i's total exports and world total exports.

If the value of RCA index is less than 1, it implies that the country has a revealed comparative disadvantage in the product. Similarly, if the RCA index exceeds 1, it means that the country has a revealed comparative advantage in that particular commodity.

\subsection{India And ASEAN-5- Economic Profile}

ASEAN countries have been making quite a positive progress over the recent years. It has a current gross domestic products (GDP) of almost US\$2.8 trillion in 2017, ASEAN is now collectively ranked as the world 5th largest and Asian 3rd largest economy. The growth rate of ASEAN's real GDP is positive during the study period. After the recovery from the Asian financial crisis in 1998-1999 with a growth rate at 6.0\% in 2000, ASEAN GDP kept on growing steadily since then, with the annual average rate at $5.3 \%$ till the year 2017 . Table 1 shows the annual

Table 1

\begin{tabular}{|c|c|c|c|c|c|c|}
\hline \multirow{2}{*}{$\begin{array}{c}\text { ASEAN-5 } \\
\text { MEMBER } \\
\text { STATES } \\
\text { AND INDIA }\end{array}$} & \multicolumn{5}{|c|}{$\begin{array}{l}\text { GDP GROWTH RATE ANNUAL (\%) OF ASEAN-5, } \\
\text { ASEAN TOTAL AND INDIA, 2000-2017 }\end{array}$} & \multirow{2}{*}{$\begin{array}{c}\begin{array}{c}\text { Annual } \\
\text { average } \\
\text { growth rate }\end{array} \\
2000-2017 \\
\end{array}$} \\
\hline & 2000 & 2005 & 2010 & 2015 & 2017 & \\
\hline Indonesia & 4.9 & 5.4 & 5.7 & 6.2 & 5.1 & 6.5 \\
\hline Malaysia & 8.9 & 5.3 & 7.4 & 5.0 & 5.9 & 7.5 \\
\hline Philippine & 4.4 & 4.8 & 7.6 & 6.1 & 6.7 & 5.9 \\
\hline Singapore & 8.9 & 7.5 & 5.2 & 3.0 & 3.6 & 6.8 \\
\hline Thailand & 4.5 & 4.2 & 7.5 & 3.0 & 3.9 & 5.4 \\
\hline India & 3.8 & 7.9 & 8.4 & 7.9 & 7.1 & 7.0 \\
\hline ASEAN TOTAL & 6.0 & 5.8 & 7.5 & 4.8 & 5.3 & 5.3 \\
\hline
\end{tabular}


The annual average growth rates during the study period was recorded the highest in case of Malaysia followed by India. The combined annual average growth rate of GDP in these ASEAN countries was $7.5 \%$ during the period. A comparison of India and ASEAN-5 countries clearly indicate that India's GDP growth rate was high among all the countries except Malaysia.

\subsection{India and ASEAN-5- Trade Profile}

\section{Patterns of trade- Inter-Industry versus Intra-Industry}

To make a comparative analysis between inter and intra industry trade, this section of the study analyses the pattern of trade between India and ASEAN-5.Figure 1 and Figure 2 shows the combined annual growth rates (CAGR) of India's inter-industry imports from ASEAN-5 and inter-industry exports to ASEAN-5 respectively. The commodities in which India has comparative advantages i.e. the commodities exported to ASEAN-5 are-pulses, palm oil, wood and products, coal, rail equipment, autos and component and filament and fibres.
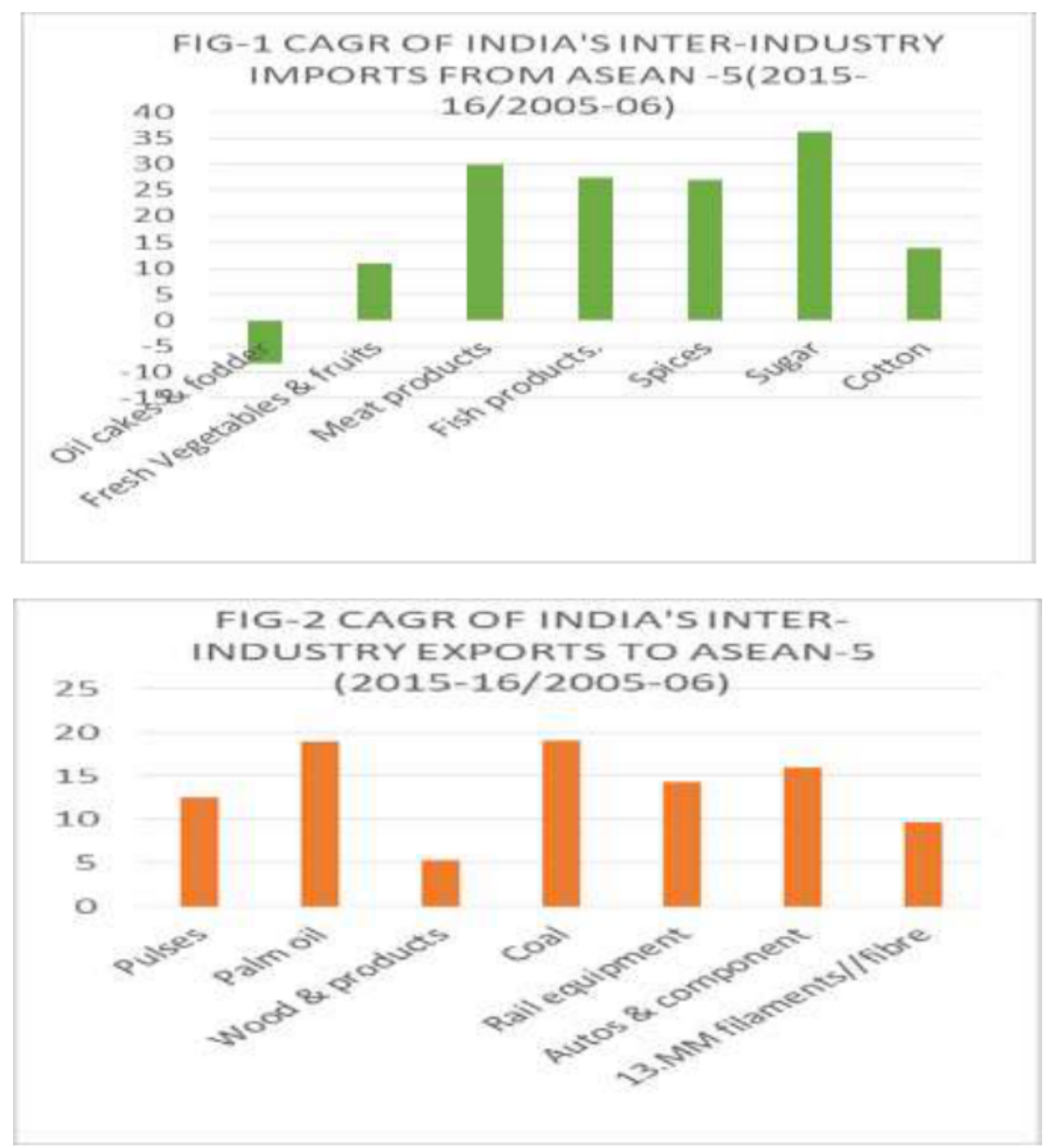

Source-author's calculation, data collected from WITS (World Integrated Trade Solutions).

The commodities in which ASEAN-5 has comparative advantages i.e. the commodities exported to India are- oil cakes and fodder, fresh vegetables and fruits, meat products, fish products, spices, sugar and cotton. It is seen that oil cakes and fodder imports experienced negative CAGR for the year 2005-06 and 2015-16, whereas all other commodities witnessed a positive growth with the highest growth in meat product imports and sugar imports. 
An Empirical Analysis of Inter-Industry and Intra-Industry Trade between India and ASEAN - The Impact of Revealed Comparative Advantage (RCA) in Commodities
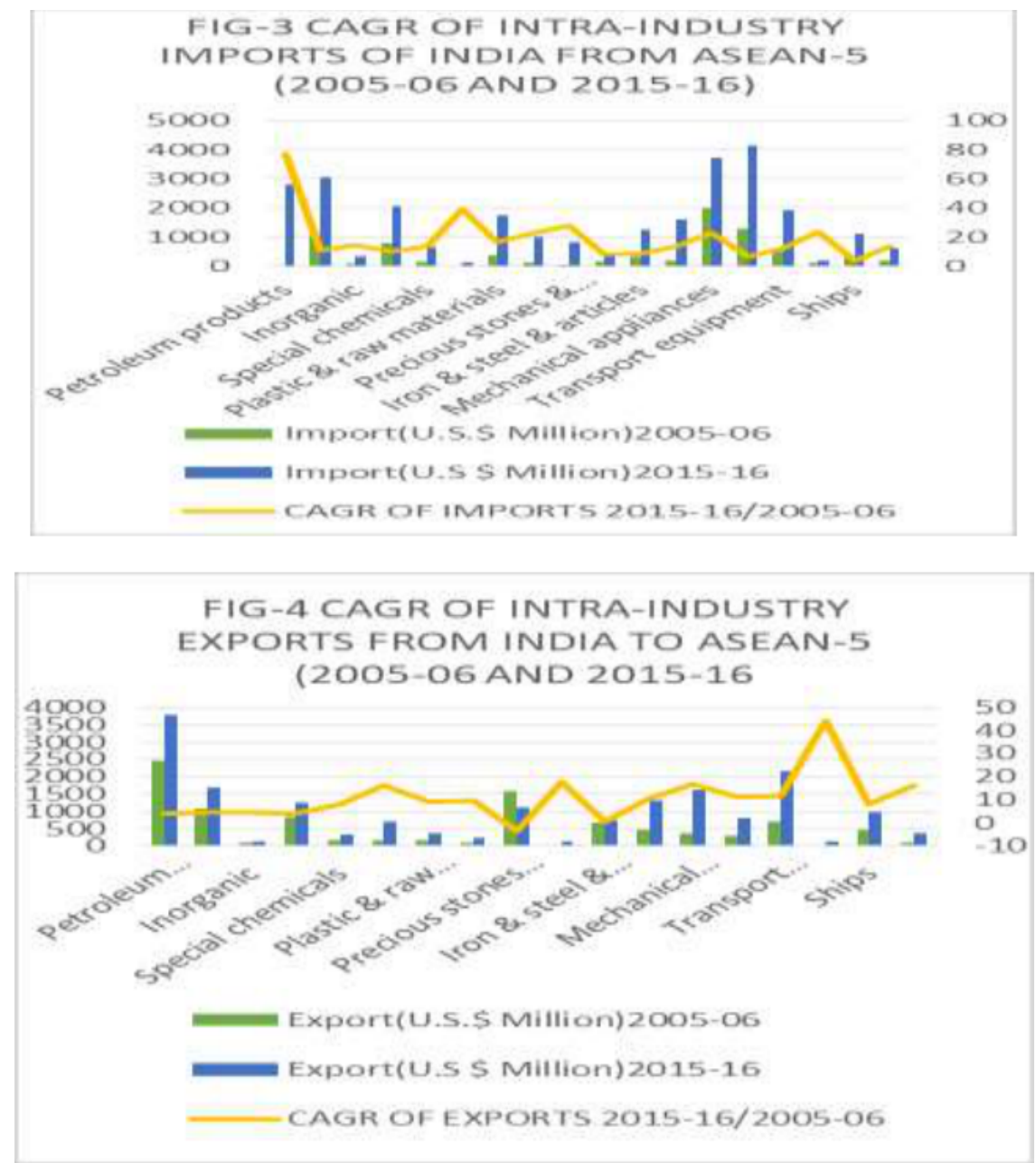

Source-author's calculation, data collected from WITS (World Integrated Trade Solutions).

Figure 3 shows the intra-industry exports from India to ASEAN-5 and the CAGR of exports for the period 2005-06 and 2015-16. The commodities in which intra-industry trade takes place are- petroleum products, inorganic and special chemicals, plastic and raw materials, precious stones and jewellery, iron and steel, transport equipment and ships. Figure 4 shows intra-industry imports of India from ASEAN-5 which obviously happens to be in the same commodities mentioned above.

An analysis of the patterns reveal that CAGR of exports from India to ASEAN-5 has been increasing over time and the CAGR of imports has been decreasing over time.

\section{REVEALED COMPARATIVE ADVANTAGE (RCA)}

Most of the newly emerging theories of international trade theory have been interested in the relationship between comparative advantages and IIT since a very long period of time. Economists like Flam and Helpman in 1987, Davis in 1995 etc. said that vertical IIT can be explained theoretically with the help of traditional trade models like Ricardo's comparative advantage model and Heckscher-Ohlin models. According to the definition given by Haberler in 1930, a country is said to have comparative advantage to produce a certain commodity. A comparative advantage is said to be "revealed" if the value of RCA index is greater than 1. In contrary, if the RCA index is less than one, the country has comparative disadvantage in the particular commodity or industry.

Figure 5 to Figure 9 below are based on the RCA index calculated for each commodities in which simultaneous imports and exports takes place between India and ASEAN-5 nation 
for the year 2000-2017. It is seen that except three or four years during the study period, all other period and commodities are seen to reveal comparative

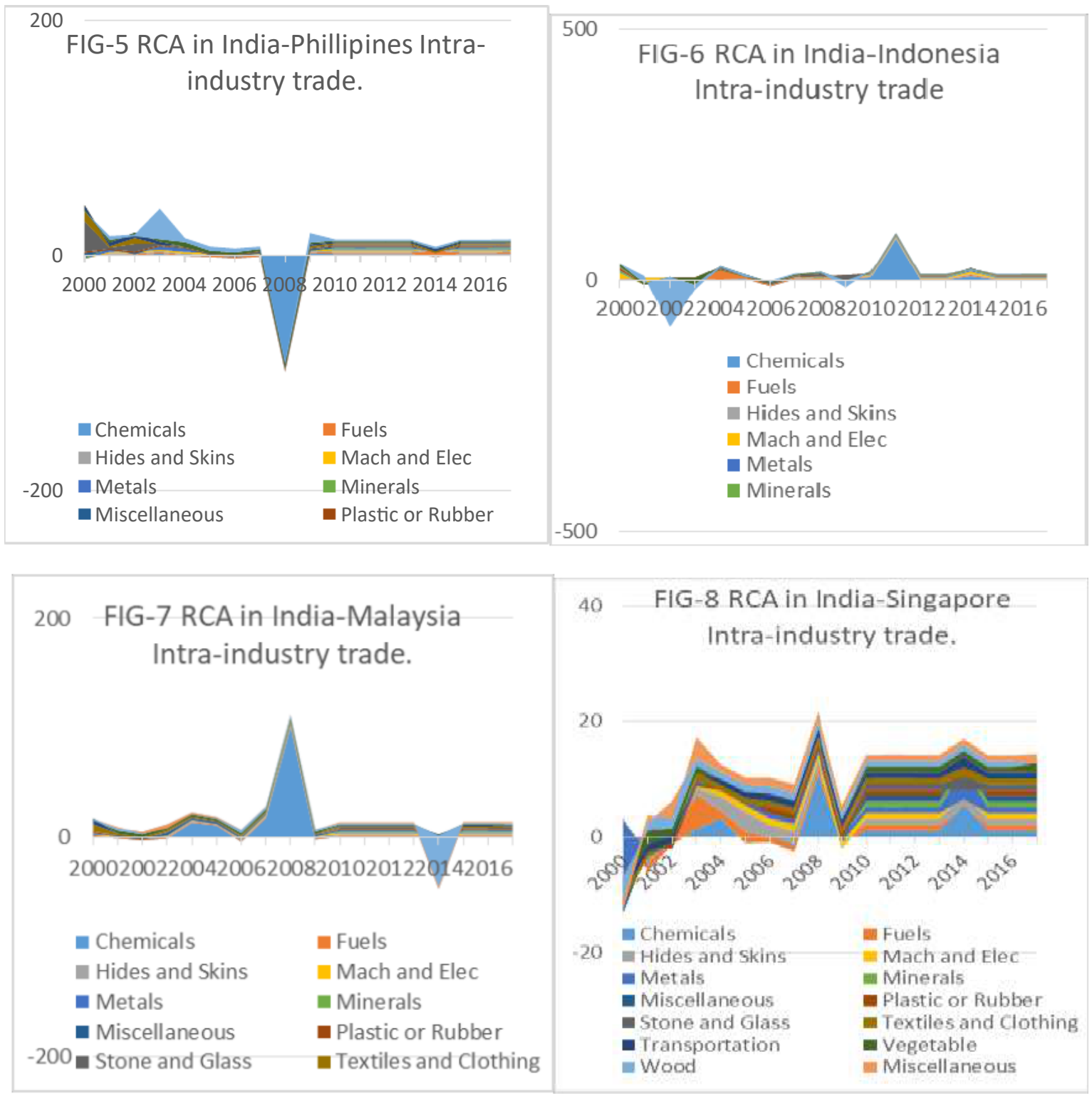

Source- based on authors own calculations.

Advantages in production. It is seen by the positively rising areas of the curves. RCA was negative for the year 2008 in case of India-Philippines trade, for 2002 in case of IndiaIndonesia trade, for the year 2014 in case for India-Malaysia trade and 2000 and 2002 for India-Singapore and India-Thailand trade respectively.

However, this revealed disadvantages is quite small if considered the time frame of the study i.e. 17 years. It implies that the advantage is much greater than the revealed comparative disadvantage when the intra-industry trade between India and ASEAN-5 nations are considered. It clearly indicates a positive correlation of RCA and level of intra-industry trade which is consistent with the findings of many empirical studies like Horácio Faustino, 2008, Das and Dubey, 2016 etc. 
An Empirical Analysis of Inter-Industry and Intra-Industry Trade between India and ASEAN - The Impact of Revealed Comparative Advantage (RCA) in Commodities

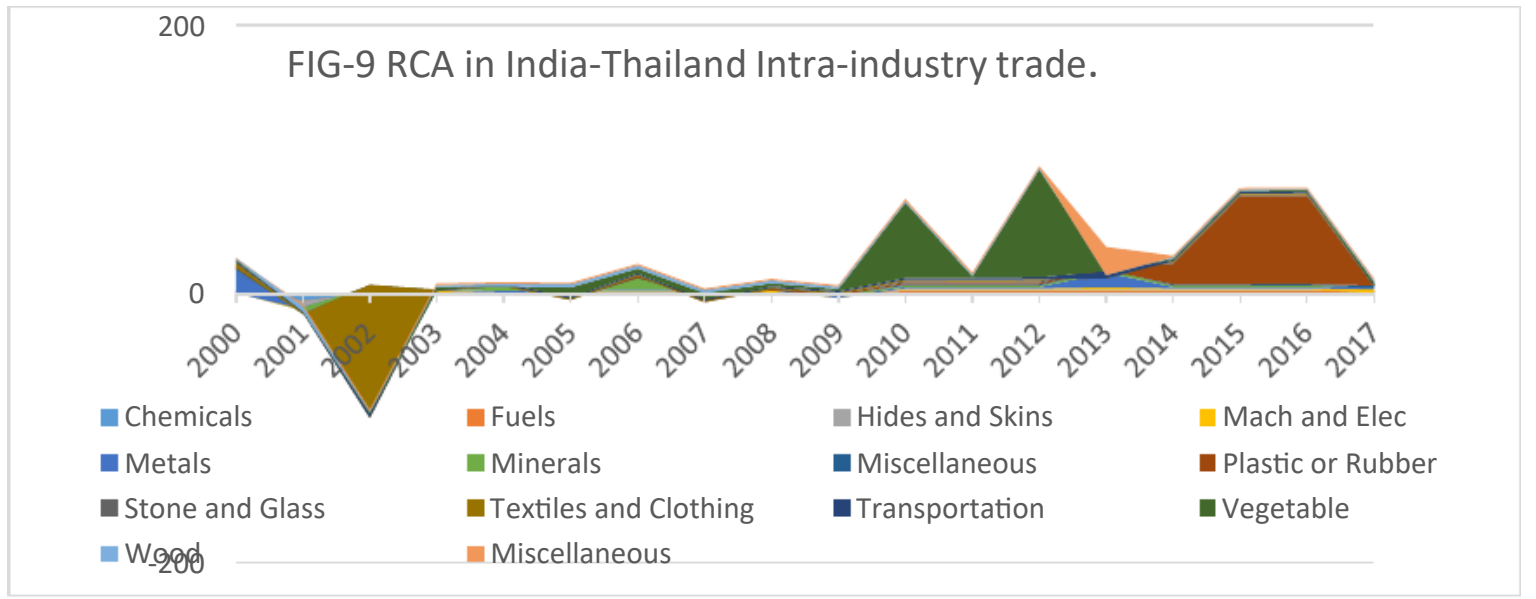

Source- based on authors own calculations.

\section{CONCLUSION}

There has been increasing importance of trade in economic development in all countries of the world. The concept of intra-industry trade although emerged late in literature, has increasing share in total trade. Trade between India and ASEAN has been quite intense since its formation and have been found to have tremendous possibility in future too. With these backdrop, this paper attempted to examine the trend and pattern of both inter-industry and intra-industry trade between India and ASEAN-5 countries. We also attempted to analyse the impact of Revealed Comparative advantage upon trade in similar products (or intra-industry trade) among these countries. We started by calculating the CAGR of imports to India from ASEAN-5 and exports from India to ASEAN-5, for both inter-industry and intra industry trade. In this study, a comparative analysis is made between both the types of trade i.e. intra and inter industry trade. Commodity wise analysis is done in this study and the commodity classification is based on ITC-HS code classification. The CAGR of inter-industry imports as well as exports have shown a positive growth over the years. In case of intra-industry trade, CAGR of exports showed an increasing trend over the years whereas CAGR of imports showed a decreasing trend indicating that there is trade surplus in intra-industry trade. A trade surplus contributes to economic growth.

To deal with the second objective, we constructed the RCA index for each commodities. The commodities in our study. In these commodities, simultaneous imports and exports have taken place between India and ASEAN-5 nations for the year 2000 to 2017. The RCA index showed overall comparative advantages for all the countries with an exception of a few years of disadvantage which is quite insignificant when the whole study period i.e. 17 years is considered. Among all the ASEAN-5 countries, India-Singapore has the greatest comparative advantages which indicates that trade facilitating policies may enhance the trade relation between India and Singapore faster than the other ASEAN countries. To conclude, the study clearly indicates a positive relation between RCA and level of intra-industry trade which is consistent with the findings of many empirical studies. Thus, the research question is answered that RCA do (positively) influence intra-industry trade among India and ASEAN-5.

\section{FUTURE SCOPE}

Future scope that this study leaves behind are- a more detailed study covering all the ASEAN nations may be made by interested researchers, the intensity of intra-industry trade between India and ASEAN may be calculated using appropriate index and the relationship between RCA and IIT may be tested using statistical and econometric tests which is left behind in this study. 


\section{REFERENCES}

[1] Das, Ram Upendra, Rishi Meenakshi and Dubey Jay Dev (2016), ASEAN plus Six and Successful FTAs: Can India Propel Intra-Industry Trade Flows? , The Journal of Developing Area Volume 50 No. 2, spring 2016.

[2] Bagchi, Sagnik,. Bhattacharyya, Surajit. (2011) Country-Specific Determinants of IntraIndustry Trade in India, Foreign Trade Review 54(3) 129-158, 2019 (C) 2019 Indian Institute of Foreign Trade.

[3] Veeramani, C. (2002). Intra-industry trade of India: Trends and country specific factors. Weltwirtschaftliches Archive, 138(3), 509-533.

[4] Veeramani, C. (2009). Trade barriers, multinational involvement and intra-industry trade: panel data evidence from India, Applied Economics, 2009, 41, 2541-2553. Static and Dynamic Panel Data, Munich Personal RePEc Archive, MPRA Paper No. 45502, posted 25 Mar 2013 10:52 UTC.

[5] Chakravartya, Smwarajit Lahiri, Chakrabarty, Ranajit. (2013). A gravity model approach to Indo-ASEAN trade-fluctuations and swings, Procedia - Social and Behavioural Sciences 133 (2014) $383-391$.

[6] Sisili, Dr.T. (2017) ,Intra Industry Trade between India and ASEAN 5 Nations, IJARIIE$\operatorname{ISSN}(O)-2395-4396$.

[7] Asean Key Figures 2018, The ASEAN Secretariat (2017), Jakarta, Indonesia

[8] India ASEAN Trade and Investment Relations: Opportunities and Challenges, The Associated Chambers of Commerce and Industry of India ASSOCHAM www.assocham. 